\title{
The influence of shear stress on the adhesion capacity of Legionella pneumophila
}

\author{
Martina Oder, Rok Fink, Klemen Bohinc, and Karmen Godič Torkar \\ Faculty of Health Sciences, University of Ljubljana, Ljubljana, Slovenia
}

[Received in October 2016; Similarity Check in October 2016; Accepted in May 2017]

\begin{abstract}
Bacterial adhesion is a complex process influenced by many factors, including hydrodynamic conditions. They affect the transfer of oxygen, nutrients, and bacterial cells in a water supply and cooling systems. The aim of this study was to identify hydrodynamic effects on bacterial adhesion to and detachment from stainless steel surfaces. For this purpose we observed the behaviour of bacterium L. pneumophila in no-flow and laminar and turbulent flow conditions simulated in a fluid flow chamber. The bacterial growth in no-flow and laminar flow conditions was almost identical in the first $24 \mathrm{~h}$, while at 48 and $72 \mathrm{~h}$ of incubation, the laminar flow stimulated bacterial growth. In the second part of this study we found that laminar flow accelerated bacterial adhesion in the first $48 \mathrm{~h}$, but after $72 \mathrm{~h}$ the amount of bacterial cells exposed to the flow dropped, probably due to detachment. In the third part we found that the turbulent flow detached more bacterial cells than the laminar, which indicates that the strength of shear forces determines the rate of bacterial removal.
\end{abstract}

KEY WORDS: bacterial growth; flow chamber; laminar flow; turbulent flow

Legionellosis is a disease caused by the gram-negative bacteria of the genus Legionella. It manifests itself as two distinct clinical syndromes: Legionnaires' disease and Pontiac fever. It spreads through inhalation of aerosols from devices such as cooling towers, hot tubs, industrial equipment, and indoor fountains (1-3).

Legionellae are ubiquitous in natural and artificial water environments worldwide and can survive extreme environmental conditions (4). Present in natural aquatic environments in low concentrations, Legionellae may enter storage tanks and water supply systems, whose physical and chemical conditions stimulate their growth (5). An important measure against their proliferation is preventing their biofilm formation, because once the biofilm has been formed, it is difficult to remove it from complex piping systems.

The first step in the formation of a biofilm is the adhesion of bacteria to surfaces. Once attached to a surface, the bacteria communicate with extracellular signals, merge, and form biofilms (6). Bacterial adhesion presents a significant problem in food and pharmaceutical industry as well as building maintenance (7-13).

Bacterial adhesion to surfaces has been studied since 1936 (14), but we still do not know everything about the formation of biofilms. Bacterial adhesion is a complicated process influenced by many factors: bacterial properties (hydrophobicity, flagellation, and motility), surface properties (hydrophobicity and roughness), and environmental factors such as temperature, $\mathrm{pH}$, presence

Correspondence to: Karmen Godič Torkar, University of Ljubljana, Faculty of Health Sciences, Department for Sanitary Engineering, Zdravstvena pot 5, 1000 Ljubljana, Slovenia, e-mail: karmen.torkar@zf.uni-lj.si of nutrients for bacteria, and hydrodynamic conditions (15, 16). Flow of water determines the transport of nutrients, oxygen, and bacterial cells that can form a biofilm (17).

One flow force that can greatly influence the physical properties of biofilms, such as density and strength, is the shear stress. Liu and Tay (18) found that biofilms exposed to high shear stress were denser than those exposed to low shear. Stoodley et al. (19) have determined that shear increases at greater unidirectional flows and that biofilm cell clusters become elongated in the downstream direction to form filamentous streamers. In contrast, Joseph et al. (20) report that the Legionella bacteria rapidly multiply in stationary water conditions at $20^{\circ} \mathrm{C}$ to $45^{\circ} \mathrm{C}$.

The aim of our study was to establish how hydrodynamic conditions affect the growth and adhesion of Legionella pneumophila. We also wanted to establish the potential of shear stress in detaching the bacteria to see if it could be used to control adhesion.

\section{MATERIALS AND METHODS}

\section{Bacteria}

We conducted our experiment on the standard strain of Legionella pneumophila subsp. pneumophila ATCC 33153 (L. pneumophila), obtained from the Czech Collection of Microorganisms (CCM, Brno, Czech Republic). Legionellae are Gram-negative microaerophiles with respiratory metabolism that do not encapsulate or sporulate. They are 2-20 $\mu \mathrm{m}$ long and 0.3-0.9 $\mu \mathrm{m}$ wide (21). Most of the known species have one or more flagella (22). 


\section{Bacterial growth, zeta potential, and contact angle}

To measure bacterial growth we incubated $L$. pneumophila in a buffered charcoal yeast extract (BCYE) medium with the addition of cysteine at $36{ }^{\circ} \mathrm{C}$ for 24,48 , and $72 \mathrm{~h}$ in accordance with the ISO standard 11731:1998 (23). One part was cultured in no-flow conditions (incubator) and another part in laminar flow conditions (flow chamber, Figure 1), in which the bacterial suspension circulated at a constant flow rate of $\mathrm{Q}_{\max }=20 \mathrm{~mL} \mathrm{~min}^{-1}$.

The attachment of microbial cells to the surfaces depends of many factors. One is the negative charge of the bacterial cell surface that interacts with positively charged material surfaces to which the bacteria attach. Simply put, the higher the charge the greater the interaction with the positively charged surfaces $(24,25)$. This interaction is known as electrophoretic (electrokinetic) mobility or zeta potential, which we measured with a Zetasizer Nano ZS (Malvern Instruments Ltd, Worcestershire, United Kingdom) and calculated according to the equation by Helmholtz-von Smoluchowski $(25,26)$. It is an indirect measure of net bacterial cell surface charge. To do that we centrifuged 24 -hour bacterial culture at $10,000 \times \mathrm{g}$ for $10 \mathrm{~min}$, resuspended the cells in a phosphate buffer solution $(\mathrm{pH} 7)$, and repeated centrifugation three times to separate the cells from the liquid medium. In the last step, we resuspended bacterial sediment in $7 \mathrm{~mL}$ of PBS buffer (0.026 g KH $\mathrm{PO}_{4}, 0.047 \mathrm{~g} \mathrm{~K}_{2} \mathrm{HPO}_{4}$ in $1 \mathrm{~L}$ ).

Another important factor affecting bacterial adhesion (attachment) is the contact angle of the bacterial cells, which tells us whether the bacterium is hydrophilic or hydrophobic (27). Hydrophobic cells adhere more strongly to hydrophobic surfaces, while hydrophilic cells prefer hydrophilic surfaces $(28,29)$. Bacterial hydrophobicity was determined as described earlier by Bohinc et al. (26) and Kurinčič et al. (30). Sample preparation was the same as described above.
After centrifugation, the cells were resuspended in $5 \mathrm{~mL}$ of $\mathrm{pH} 7 \mathrm{PBS}$ buffer and we added $1 \mathrm{~mL}$ of xylene to $2.5 \mathrm{~mL}$ of bacterial cell suspension, mixed on a vortex mixer for 2 min and incubated at $20{ }^{\circ} \mathrm{C}$ for $20 \mathrm{~min}$ to allow for separation of the two phases. The absorbance of bacterial suspension in PBS buffer and the lower aqueous phase were measured at the wavelength of $620 \mathrm{~nm}$. Contact angle was calculated with the following formula:

$$
h=\left(A_{i}-A_{f}\right) / A_{i}
$$

where $h$ is hydrophobicity rate, $A_{i}$ the absorbance of the initial bacterial suspension, and $A_{f}$ the absorbance of the aqueous phase after mixing with xylene (26).

\section{Flow chamber measurements}

To measure bacterial growth, attachment, and detachment we used a flow chamber with external dimensions of $399 \times 325 \times 265 \mathrm{~mm}$ (31). Figure 1 shows the heating/cooling chamber on the left and the flow cell with connector for turbulent and laminar flows on the right. For flow we used two peristaltic pumps: one for laminar flow

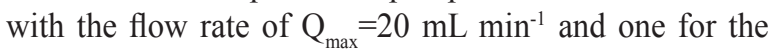
turbulent flow rate of $Q_{\max }=1200 \mathrm{~mL} \mathrm{~min}^{-1}$.

\section{Laminar flow effect on bacterial adhesion}

L. pneumophila colonies were counted on plates after 24,48 , and $72 \mathrm{~h}$. For the medium we used $1 \mathrm{~mL}$ of serial 10 -fold dilution with $0.9 \% \mathrm{NaCl}$ solution (from $10^{-4}$ to $10^{-9}$ ) mixed with melted nutrient agar.

To measure the effects of laminar flow on the adhesion of $L$. pneumophila we inserted clean and sterile $2 \mathrm{~mm}$ thick $20 \times 20 \mathrm{~mm}$ AISI 304 stainless steel coupons (Iskra Pio, Šentjernej, Slovenia) into the flow chamber and exposed them to the bacterial culture in liquid medium. The surface topography of the coupons was analysed with atomic force microscopy (AFM VEECO Dimension 3100, CSInstruments,

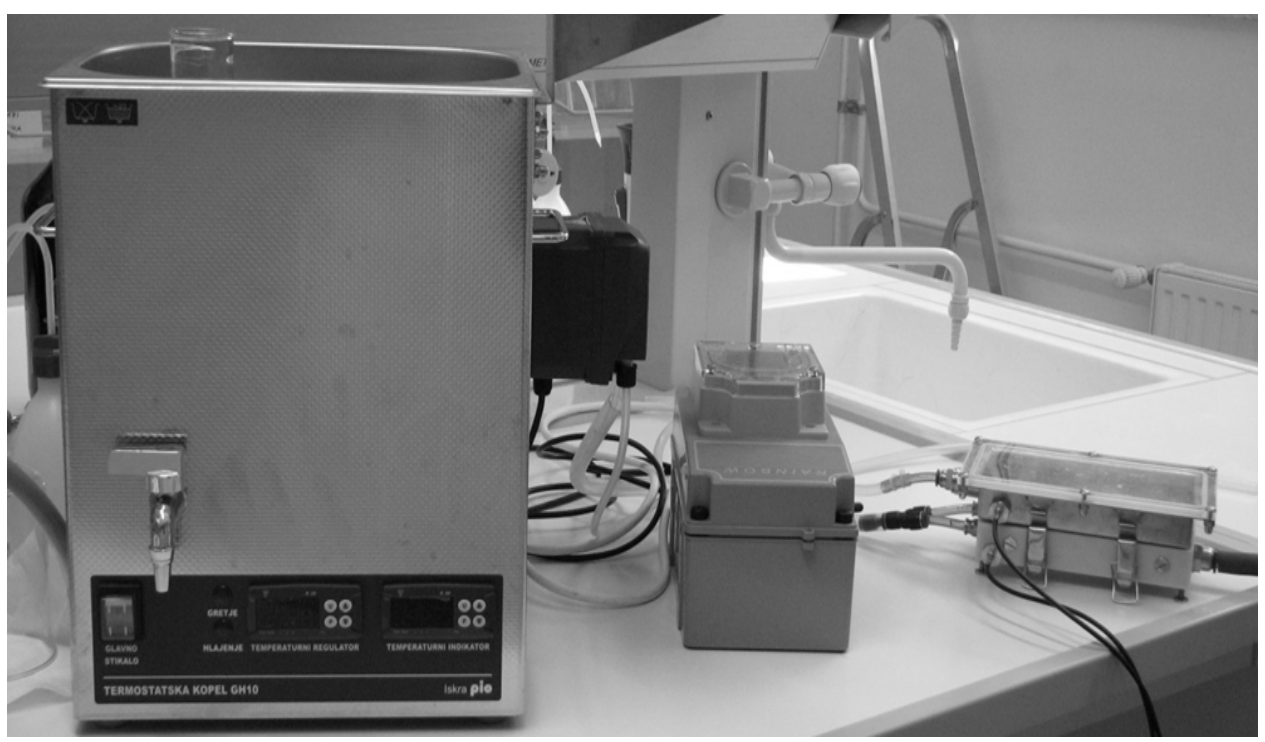

Figure 1 The system of liquid flow chamber with a cooling / heating unit (left), a polyethylene tray (right) and a peristaltic pump to determine the effect of laminar and turbulent flow on the attachment and detachment of microorganisms from material surfaces 
Les Ulis, France). The coupons were rinsed with $300 \mathrm{~mL}$ of bacterial culture (5.5 $\log \mathrm{CFU} \mathrm{m \textrm {m } ^ { - 1 } )}$ using a peristaltic pump with constant laminar flow rate of $20 \mathrm{~mL} \mathrm{~min}^{-1}$ at $36{ }^{\circ} \mathrm{C}$. Adhesion was measured after 24,48 , and $72 \mathrm{~h}$ by staining the coupons with bacterial cells with $3 \mathrm{~mL}$ of $0.1 \%$ crystal violet suspension (Merck, Darmstadt, Germany) at room temperature for $3 \mathrm{~min}$. The coupons were then rinsed three times with PBS buffer. The dye in the cells was remobilised in $2 \mathrm{~mL} 96 \%$ ethanol. The absorbance of the dye solution was measured spectrophotometrically at the wavelength of $620 \mathrm{~nm}$ with a microplate reader Infinite $200^{\circledR}$ PRO (Tecan GmbH, Gröding, Austria). For negative control we used four samples of metal coupons without bacteria.

\section{Laminar and turbulent flow effects on bacterial detachment}

To measure the effects of laminar and turbulent flow on bacterial detachment, we exposed the coupons to bacterial cultures in the ratio of 1:30 and incubated them in 6-well microtiter plates at $36{ }^{\circ} \mathrm{C}$ for $72 \mathrm{~h}$. After a 72 -hour incubation, the coupons were exposed to the laminar flow of $1 \mathrm{~L}$ PBS buffer at a constant rate of $20 \mathrm{~mL} \mathrm{~min}^{-1}$ or to the turbulent flow of $1200 \mathrm{~mL} \mathrm{~min}^{-1}$ or to no-flow conditions with PBS buffer. Optical density was determined using the crystal violet assay as described above. For negative control we used metal coupons without bacteria and exposed them to the same conditions.

\section{Statistical analysis}

Statistical analysis was run on R software version 3.1.3 (Bell Laboratories, New Jersey, NJ, USA). It included paired Student's $t$-test of average optical densities of the attached and detached bacteria. The significance level was set at $p<0.05$.

\section{RESULTS AND DISCUSSION}

\section{Zeta potential, contact angle, and bacterial growth}

Our measurements have shown that L. pneumophila is hydrophilic ( $\mathrm{h}=43 \%)$. The contact angle of the brushed metal coupons was $74^{\circ}$, which means that the coupon surfaces were hydrophilic too and that the adhesion should be stronger. The cell-specific fimbriae and flagella (32) of L. pneumophila compensate for the hydration force between the cell and the material surface (33).

Figure 2 shows that no-flow conditions did not simulate bacterial growth, which is in contrast with the findings reported by Joseph et al. (20). The growth curves for noflow and laminar flow conditions were almost identical in the first $24 \mathrm{~h}$, while at 48 and $72 \mathrm{~h}$ of incubation, laminar flow stimulated bacterial growth, and the difference in CFU between no flow and laminar flow was about $0.4 \mathrm{log}$ CFU $\mathrm{mL}^{-1}$.

\section{Laminar flow effect on bacterial adhesion}

The second experiment aimed at determining the effects of laminar flow on L. pneumophila adhesion to metal coupons. Figure 3 shows adhesion under laminar flow and no-flow conditions. In the first 24 and $48 \mathrm{~h}$ of incubation, bacterial adhesion was higher under laminar flow, but after $72 \mathrm{~h}$, adhesion was higher under no-flow conditions. Differences in adhesion (determined through optical density) between no flow and laminar flow were statistically significant for all three incubation times (Table 1). In no-

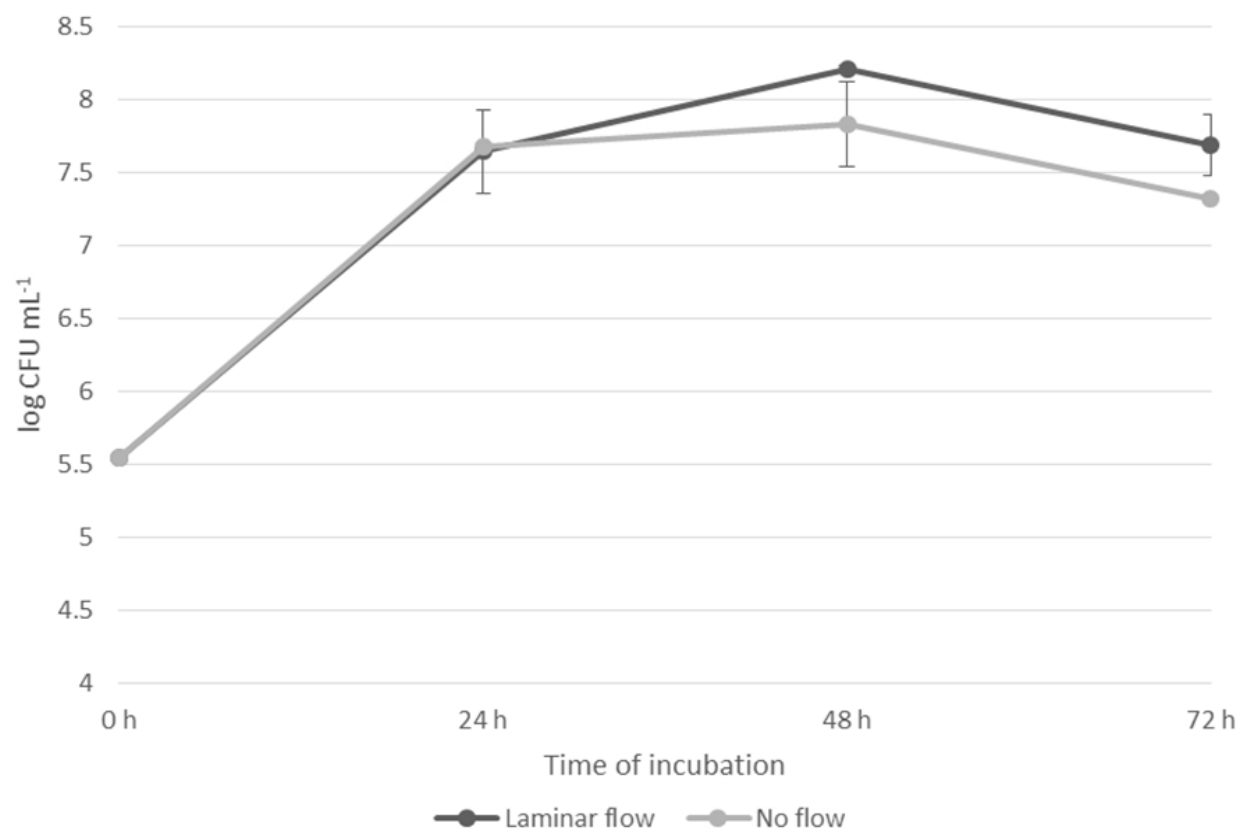

Figure 2 L. pneumophila growth curve in no-flow and laminar flow conditions 


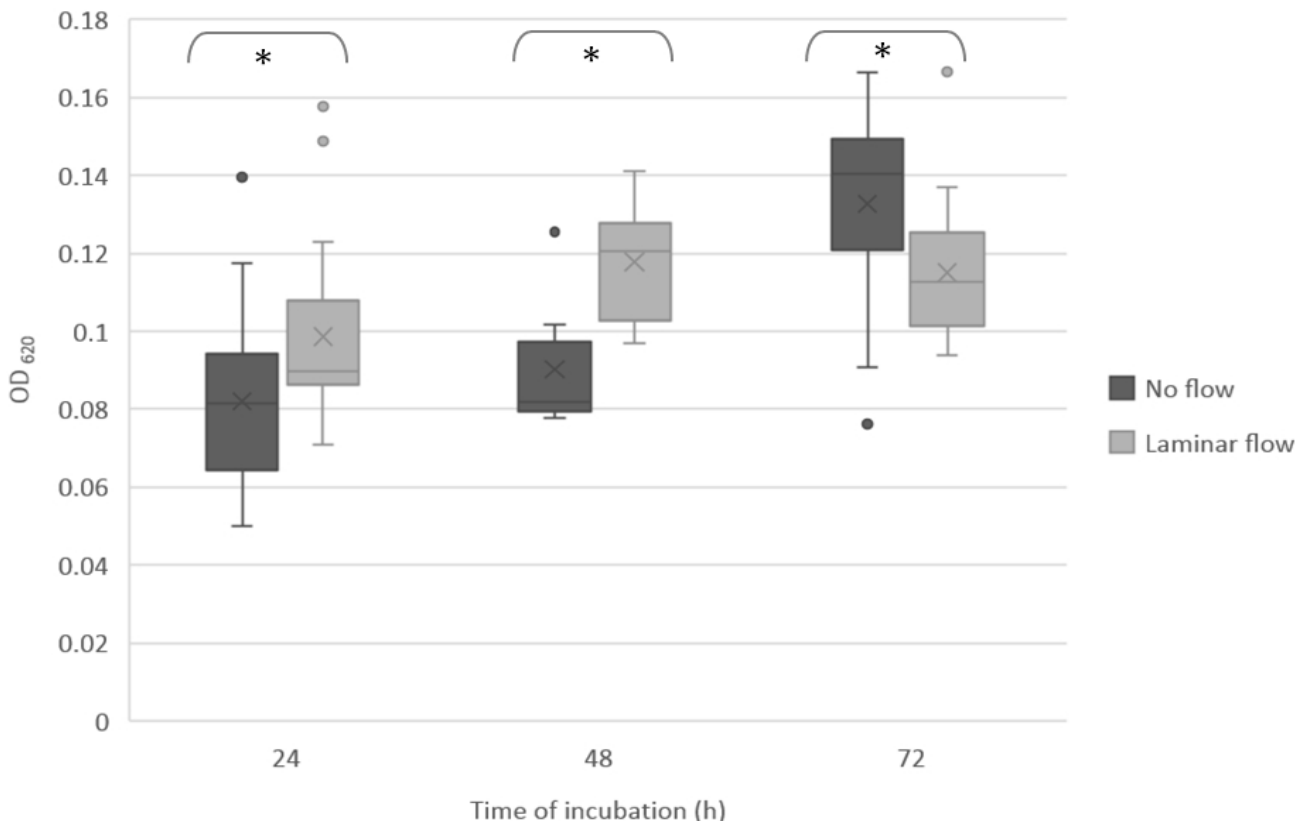

Figure 3 L. pneumophila adhesion on metal coupons in no-flow and laminar flow conditions; $O D_{620}$ - optical density of CV dye; ${ }^{*}<<0.05$

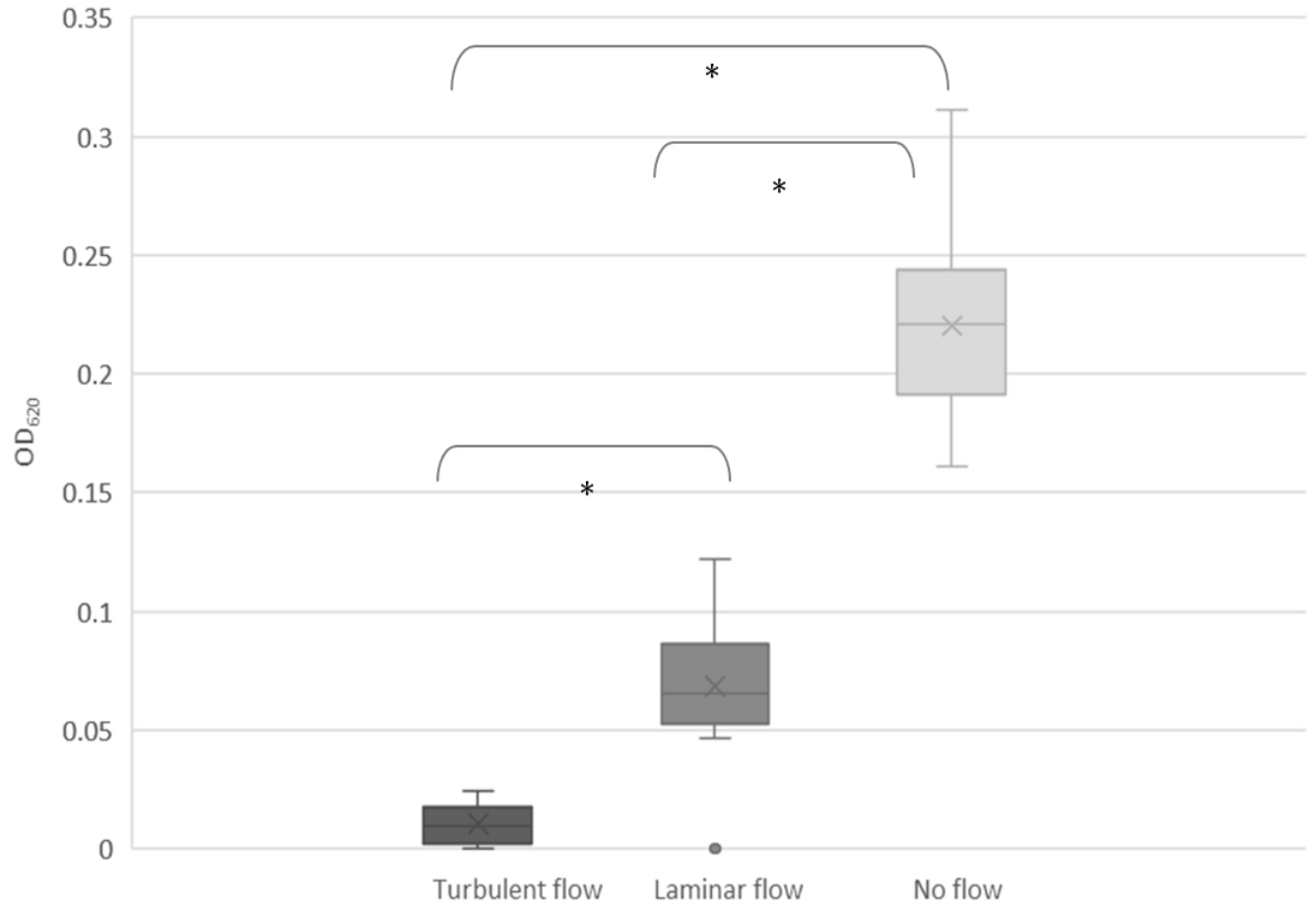

Figure 4 The effect of turbulent and laminar flow on the removal of adherent L. pneumophila subsp. pneumophila ATCC 33152 (expressed as the $O D_{620}$ of $C V$ dye) from the surface of metal coupons after 72 hours of incubation at a temperature of $36^{\circ} \mathrm{C}$; $O D_{620}$ - optical density of $C V$ dye; ${ }^{*} p<0.05$ 
Table 1 Differences in optical density between cells attached to metal coupons in no-flow, laminar flow, and turbulent flow conditions (Student's t-test)

\begin{tabular}{|c|c|c|c|c|c|c|}
\hline \multicolumn{7}{|c|}{ Effects of laminar flow on the adhesion of $L$. pneumophila } \\
\hline Time of incubation & OD no flow & & OD laminar & & Difference in OD & $t$-value \\
\hline 24 hour & 0.08 & & 0.10 & & $0.02 *$ & -5.16 \\
\hline 48 hour & 0.09 & & 0.12 & & $0.03 *$ & -10.42 \\
\hline 72 hour & 0.13 & & 0.11 & & $0.02 *$ & 2.61 \\
\hline \multicolumn{7}{|c|}{ Effects of laminar and turbulent flow on the detachment of $L$. pneumophila } \\
\hline Exposed to shear for & & OD 1 & & OD 2 & Difference in OD & $t$-value \\
\hline Turbulent (1) vs lamin & $(2)$ & 0.01 & & 0.07 & $0.06^{*}$ & -16.19 \\
\hline Turbulent (1) vs no flo & & 0.01 & & 0.22 & $0.21 *$ & -37.65 \\
\hline Laminar (1) vs no flov & & 0.07 & & 0.22 & $0.15^{*}$ & -22.46 \\
\hline
\end{tabular}

$O D$ - optical density of $C V$ dye; $* p<0.05$

flow conditions adhesion kept increasing with incubation time. Under laminar flow, it dropped at $72 \mathrm{~h}$, which suggests that the bacterial cells most likely detached themselves from the surface. This was also observed by Teodósio et al. (34), who reported that microbial detachment from a surface depends on the magnitude and direction of detachment forces, and by Liu and Li (35), who established that fluid flow can be one of the main causes of biofilm detachment. Bakker et al. (36) reported that shear stress between 6 and $8 \mathrm{~Pa}$ was sufficient to prevent adhesion of $P$. fluorescens to stainless steel and that a wall shear stress of $12 \mathrm{~Pa}$ could remove the attached cells.

\section{Laminar and turbulent flow effects on bacterial detachment}

The third experiment determined the effect of shear forces on the detachment of L. pneumophila that had previously adhered to surfaces. Figure 4 shows that turbulent flow, which generates very strong shear forces, removed almost all the bacterial cells from the metal surfaces. The less intensive rinsing with laminar flow also detached significantly more bacteria from coupon surface than no flow at all. Table 1 shows differences in detachment between turbulent flow, laminar flow, and no flow. They were significant between turbulent and no flow, laminar and no flow, and between laminar and turbulent flow. Our earlier study (31) showed that laminar and turbulent flow can remove between $80 \%$ and $90 \%$ of bacterial population from material surface. Combined with a washing agent at $37^{\circ} \mathrm{C}$ turbulent flow can remove more than $95 \%$ of bacteria. Choi and Morgenroth (37) studied the impact of shear stress on a mixed-culture biofilm and found that a sudden increase in shear stress also caused significant detachment of bacteria from the biofilm.

\section{CONCLUSIONS}

Our findings show that laminar flow promotes the growth of L. pneumophila, although some of the research indicates that no-flow conditions are more favourable. Therefore, dead legs in water supply systems do not present as much of a problem as we have thought. Instead, we should pay more attention to laminar flow, as it seems to favour bacterial adhesion to surfaces, but only in the first 48 hours. After 72 hours, bacterial cells start to detach.

In no-flow conditions biofilm continued to form throughout the 72 hours. Bacteria in the pieces of a detached biofilm can reattach to new surfaces downstream of the system. Moreover, in the third experiment, we have demonstrated that turbulent and laminar flow significantly detach L. pneumophila from surfaces. These results indicate that shear forces can be used to remove bacterial cells from water supply systems. In fact, they are already being used in food and pharmaceutical industry, and such a system is known as "cleaning-in-place" (CIP). Our future research will focus on the most efficient methods for biofilm removal in water supply systems.

\section{Acknowledgments}

The authors wish to thank Goran Dražić and his team from the Institute Jožef Stefan in Ljubljana for providing the Zetasizer Nano ZS to measure the zeta potential and the company Iskra Pio, Šentjernej for providing the coupons.

\section{REFERENCES}

1. Heng BH, Goh KT, Ng DL, Ling AE. Surveillance of legionellosis and Legionella bacteria in the built environment in Singapore. Ann Acad Med Singapore 1997;6:557-65. PMID: 9494658

2. Den Boer JW, Yzerman EPF, Schellekens J, Lettinga KD, Boshuizen, HC, Van Steenbergen JE, Bosman A, Van den Hof S, Van Vliet HA, Peeters MF, Van Ketel RJ, Speelman P, Kool JL, Van Spaendonck MAEC. A large outbreak of Legionnaires' disease at a flower show, the Netherlands, 1999. Emerg Infect Dis 2002; 8:37-43. PMCID: PMC2730281

3. Greig JE, Carnie JA, Tallis GF, Ryan NJ, Tan AG, Gordon IR, Zwolak B, Leydon JA, Guest CS, Hart WG. An outbreak of Legionnaires' disease at the Melbourne Aquarium, April 
2000: investigation and case-control studies. Med J Australia 2004; 180: 566-72. PMID: 15174987

4. Fliermans CB, Cherry WB, Orrison LH, Smith SJ, Tison DL, Pope SH. Ecological distribution of Legionella pneumophila. Appl Environ Microbiol 1981;41:9-16. PMCID: PMC243633

5. Surman-Lee S, Fields B, Hornei B, Ewig S, Exner M, Tartakovsky I, Lajoie L, Dangendorf F, Bentham R, Cabanes PA, Fourrier P, Trouvet T, Wallet F. Ecology and environmental sources of Legionella. In: Bartram J, Chartier Y, Lee JV, Pond $\mathrm{K}$, Surman-Lee S, editors. Legionella and the prevention of legionellosis. 1st ed. Geneva: WHO Press; 2007. p. 29-38.

6. Rendueles O, Ghigo JM. Multi-species biofilms: how to avoid unfriendly neighbors. FEMS Microbiol Rev 2012;36:972-89. doi: 10.1111/j.1574-6976.2012.00328.x

7. Costerton JW, Stewart PS, Greenberg EP. Bacterial biofilms: a common cause of persistent infections. Science 1999;284:1318-22. doi: 10.1126/science.284.5418.1318

8. Stewart PS, Costerton JW. Antibiotic resistance of bacteria in biofilms. Lancet 2001;358:135-8. doi: 10.1016/S01406736(01)05321-1

9. Coquet L, Cosette P, Junter GA, Beucher E, Saiter JM, Jouenne T. Adhesion of Yersinia ruckeri to fish farm materials: influence of cell and material surface properties. Colloids Surf B 2002;26:373-8. doi: 10.1016/S09277765(02)00023-1

10. Teixeira P, Silva S, Araújo F, Azeredo J, Oliveira R. Bacterial adhesion to food contacting surfaces. In: Mendez-Vilas A, editor. Communicating current research and educational topics and trends in applied microbiology. Vol. 1. Formatex, 2007. p. 13-20.

11. Rogers J, Dowsett AB, Dennis PJ, Lee JV, Keevil CW. Influence of plumbing materials on biofilm formation and growth of Legionella pneumophila in potable water systems. Appl Environ Microbiol 1994;60:1842-51. PMCID: PMC201571

12. Türetgen I, Cotuk A. Monitoring of biofilm-associated Legionella pneumophila on different substrata in model cooling tower system. Environ Monit Assess 2007;125:2719. doi: 10.1007/s10661-006-9519-8

13. Moritz MM, Flemming H, Wingender J. Integration of Pseudomonas aeruginosa and Legionella pneumophila in drinking water biofilms grown on domestic plumbing materials. Int J Hyg Environ Heal 2010;213:190-7. doi: 10.1016/j.ijheh.2010.05.003

14. Vickery K, Pajkos A, Cossart Y. Removal of biofilm from endoscopes: Evaluation of detergent efficiency. Am J Infect Control 2004;32:170-6. doi: 10.1016/j.ajic.2003.10.009

15. Katsikogianni M, Missirlis YF. Concise review of mechanisms of bacterial adhesion to biomaterials and of techniques used in estimating bacteria-material interactions. Eur Cells Mater 2004;8:37-57. PMID: 15593018

16. Di Bonaventura G, Piccolomini R, Paludi D, D’Orio V. Influence of temperature on biofilm formation by Listeria monocytogenes on various food-contact surfaces: relationship with motility and cell surface hydrophobicity. J Appl Microbiol 2008;104:1552-61. doi : 10.1111/j.1365-2672.2007.03688.x

17. Simões LC, Simões M, Oliveira R, Vieira MJ. Potential of the adhesion of bacteria isolated from drinking water to materials. J Basic Microbiol 2007;47:174-83. doi: 10.1002/ jobm.200610224
18. Liu Y, Tay JH. Metabolic response of biofilm to shear stress in fixed-film culture. J Appl Microbiol 2001;90:337-42. doi: 10.1046/j.1365-2672.2001.01244.x

19. Stoodley P, Lewandowski Z, Boyle JD, Lappin-Scott HM. Structural deformation of bacterial biofilms caused by short term fluctuations in flow velocity: an in-situ demonstration of biofilm viscoelasticity. Biotechnol Bioeng 1999;65:83-92. doi: 10.1002/(SICI)1097-0290(19991005)65:1<83::AIDBIT10>3.0.CO;2-B

20. Joseph C, Lee J, van Wijngaarden J, Drasar V, CastellaniPastoris M. European Guidelines for the control and prevention of travel associated legionnaires' disease (Draft). EWGLI - EC DG Health and Consumer Protection. Junij 2001:1-66.

21. Winn WC Jr. Legionnaires disease: historical perspective. Clin Microbiol Rev 1988;1:60-81. PMCID: PMC358030

22. Brenner DJ, Feeley JC, Weaver RE. Family VIII Legionellaceae. In: Krieg NR, Holt JG, editors. Bergey's manual of systematic bacteriology. 2nd ed. Baltimore (MD); Williams and Wilkins; 1984. p. 210-36.

23. ISO 11731:1998. Water quality - Detection and enumeration of Legionella.

24. Lage OM, Bondoso J, Catita JAM. Determinationof zeta potential in Planctomycetes and its application in heavy metal toxicity assessment. Arch Microbiol 2012;194:847-55. doi: 10.1007/s00203-012-0818-x

25. Heimenz PC, Rajagopalan R. Principles of Colloid and Surface Chemistry. $3^{\text {rd }}$ edition. New York (NY): CRC Press; 1997.

26. Bohinc K, Dražič G, Fink R, Oder M, Jevšnik M, Nipič D, Godič Torkar K, Raspor P. Available surface dictates microbial adhesion capacity. Int J Adhes Adhes 2014;50:65272. doi: 10.1016/j.ijadhadh.2014.01.027

27. Van Loosdrecht M, Norde W, Zehnder A. Physical chemical description of bacterial adhesion. J Biomater Appl 1990;5: 91-106 10.1177/088532829000500202

28. Kochkodan V, Tsarenko S, Potapchenko N, Kosinova V, Goncharuk V. Adhesion of microorganisms to polymer membranes: a photobactericidal effect of surface treatment with TiO2. Desalination 2008;220:380-385. doi:10.1016/j. desal.2007.01.042

29. Giaouris E, Chapot-Chartier M, Briandet R. Surface physicochemical analysis of natural Lactococcus lactis strains reveals the existence of hydrophobic and low charged strains with altered adhesive properties. Int J Food Microbiol 2009;131:2-9. doi:10.1016/j.ijfoodmicro.2008.09.006

30. Kurinčič M, Jeršek B, Klančnik A, Smole Možina S, Fink R, Dražić G, Raspor P, Bohinc K. Effects of natural antimicrobials on bacterial cell hydrophobicity, adhesion, and zeta potential. Arh Hig Rada Toksikol 2016;67:37-43. doi: 10.1515/aiht-2016-67-2720

31. Fink R, Oder M, Rangus D, Raspor P, Bohinc K. Microbial adhesion capacity. Influence of shear and temperature stress. Int J Environ Health Res 2014;25:656-69. doi: 10.1080/09603123.2015.1007840

32. Rosenberg M, Kjelleberg S. Hydrophobic interactions in bacterial adhesion. In: Marshal KC, editor. Advances in microbial ecology. $1^{\text {st }}$ ed. New York (NY): Springer Science Busines Media; 1986. p. 353-93.

33. Corpe W. Microbial surface components involved in adsorption of microorganisms onto surfaces. In: Bitton G, Marshall KC, editors. Adsorption of microorganisms to 
surfaces. New York (NY): John Wiley \& Sons, Inc.; 1980. p. 105-44.

34. Teodósio JS, Simões M, Melo LF, Mergulhão FJ. Flow cell hydrodynamics and their effects on E.coli biofilm formation under different nutrient conditions and turbulent flow. Biofouling 2011;27:1-11. doi: 10.1080/08927014.2010. 535206

35. Liu Y, Li J. Role of Pseudomonas aeruginosa biofilm in the initial adhesion, growth and detachment of Escherichia coli in porous media. Environ Sci Technol 2008;42:443-9. doi: $10.1021 / \mathrm{es} 071861 \mathrm{~b}$
36. Bakker DP, van der Mats A, Verkerke GJ, Busscher HJ, van der Mei HC. Comparison of velocity profiles for different flow chamber designs used in studies of microbial adhesion to surfaces. Appl Environ Microbiol 2003;69:6280-7. doi: 10.1128/AEM.69.10.6280-6287.2003

37. Choi YC, Morgenroth E. Monitoring biofilm detachment under dynamic changes in shear stress using laser-based particle size analysis and mass fractionation. Water Sci Technol 2003;47:69-76. PMID: 12701909

\section{Vpliv strižnih sil na adhezijo bakterije Legionella pneumophila}

Oprijem bakterijskih celic je kompleksen proces, ki je odvisen od mnogih dejavnikov, kot so hidrodinamični pogoji, ki vplivajo tudi na prenos kisika, hranila in tudi bakterijskih celice po sistemu. Cilj te raziskave je bil analizirati vpliv hidrodinamičnih pogojev na bakterijsko razmnoževanje, na adhezijo bakterij na površine in na odcepljanje celic iz površin iz nerjavnega jekla. Opazovali smo bakterije v pogojih brez toka in v dinamičnih pogojih. Uporabili smo sistem pretočne komore, ki simulira laminarni in turbulentni tok. Razmnoževanje bakterij je bilo v pogojih brez toka in v pogojih $\mathrm{z}$ laminarnim tokom prvih 24 ur in 48 ur skoraj enako, po 72 urah inkubacije pa je laminarni tok pozitivno vplival na bakterijsko razmnoževanje. V drugem delu naše raziskave smo ugotovili, da laminarni tok pospešuje bakterijsko adhezijo prvih 48 ur, po 72 urah pa je količina oprijetih bakterijskih celic, ki so bile izpostavljene laminarnemu toku manjša, v primerjavi s tistimi, ki so bile v pogojih brez toka. Predvidevamo, da je prišlo do odcepljanja celic iz površin. V tretjem delu raziskave smo ugotovili, da je turbulentni tok odstranil bistveno več bakterijskih celic iz površin kot laminarni tok $(\mathrm{p}<0.05)$, kar kaže na to, da moč strižnih sil določa stopnjo odstranjenih bakterijskih celic. 